\title{
DNA Polymerase Delta Catalytic Subunit
}

National Cancer Institute

\section{Source}

National Cancer Institute. DNA Polymerase Delta Catalytic Subunit. NCI Thesaurus. Code C106226.

DNA polymerase delta catalytic subunit (1107 aa, $124 \mathrm{kDa}$ ) is encoded by the human POLD1 gene. This protein is involved in both DNA leading strand synthesis and Okazaki fragment completion. 